\title{
Synthetic arsenic sulfides in Japanese prints of the Meiji period
}

\author{
Yanbing Luo ${ }^{1}$, Elena Basso ${ }^{2}$, Henry D. Smith $\|^{3}$ and Marco Leona ${ }^{2 *}$
}

\begin{abstract}
A multi-analytical investigation of Japanese woodblock prints ranging in date from 1864 to 1895 and covering essentially the time span between the very end of the Edo period and the middle of the Meiji period showed a widespread use of arsenic sulfides for yellow and green colored areas (the latter obtained by mixing Prussian blue to the yellow arsenic sulfides). Analysis by optical microscopy, X-ray fluorescence spectroscopy, Raman microscopy, and Scanning Electron Microscopy confirmed that the yellow pigment is usually a compound belonging to the solid solution series $\left(\mathrm{As}_{8} \mathrm{~S}_{8}\right)-\left(\mathrm{As}_{8} \mathrm{~S}_{9}\right)$. The poor crystallinity of the pigment as shown by Raman microscopy, the non-stoichiometric $\mathrm{As} / \mathrm{S}$ ratio, as well as the presence of excess uncombined sulfur point to a synthetic origin for the pigment. Period literary sources suggest that synthetic arsenic sulfide pigments manufacture might have started in the Iwashiro province in 1846. This is to our knowledge the first conclusive evidence for the use of synthetic arsenic sulfides in woodblock prints in Japan.
\end{abstract}

Keywords: Japanese woodblock prints, Synthetic arsenic sulfides, Alacranite, Micro-Raman spectroscopy, Micro-XRF, SEM-EDS

\section{Background}

Because of their vivid colors, ranging from yellow to red, arsenic sulfides were used as pigments since ancient times [1, 2]. Natural arsenic sulfide pigments differ for their As:S ratios, and include realgar $(\alpha-A s S)$, parareal$\operatorname{gar}\left(\beta\right.$-AsS), and orpiment $\left(\mathrm{As}_{2} \mathrm{~S}_{3}\right)$. Realgar, a widely used orange/red pigment, occurs in low-temperature hydrothermal deposits [3-5]. Pararealgar is the light-induced degradation yellow form of realgar and alacranite $[6,7]$. Mixtures of pararealgar and/or realgar have been systematically observed in many studies [8-10]. Orpiment was widely used as a yellow colorant besides yellow ochre since ancient times [11]. Another arsenic sulfide, alacranite $\left(\mathrm{As}_{8} \mathrm{~S}_{9}\right)$ [12] is a rather uncommon red mineral showing a complicated crystallographic structure where clusters of $\mathrm{As}_{4} \mathrm{~S}_{4}$ (realgar-type) and $\mathrm{As}_{4} \mathrm{~S}_{5}$ coexist in an ordered cagelike structure [3]. Although rare in nature, alacranite has been documented in works of art as a possible artificial product deriving from the arsenolite

\footnotetext{
*Correspondence: marco.leona@metmuseum.org

2 Department of Scientific Research, The Metropolitan Museum of Art, 1000 Fifth Avenue, New York, NY 10028, USA

Full list of author information is available at the end of the article
}

smelting [13-15]. The production of artificial orpiment in Western Europe was first mentioned by Johannes Alcherius in his recipe collection (1380-1420) [16], but the very first description of this synthetic pigment was made by Cennino Cennini in his treatise [17]. According to these and later sources artificial orpiment was initially obtained by sublimation, using the dry-process method [15]. The wet-process method, which produces a yellow precipitate, was introduced at the end of the nineteenth century [2 and references therein, 18].

Characterizing arsenic sulfide pigments and accurately distinguishing between natural and synthetic origin is a challenging chemical and crystallographic problem which requires a multi-analytical approach. Techniques such as polarized light microscopy (PLM), micro-Raman spectroscopy (RM), X-Ray Fluorescence spectrometry, X-Ray Diffraction (XRD), Scanning Electron Microscopy with Energy Dispersive microanalysis (SEM-EDS) [15] are best suited to this task: some of them allow noninvasive analysis while others require microsampling. An in-depth study carried out on natural and artificial orpiment, the latter obtained through both wet- and dry-process, pointed out how only the results from the 
combination of several techniques allowed to identify the actual nature of the pigment $[2,14]$. In particular, the presence of spherules of arsenic sulfide glass or alacranite solid solution series $\left(\mathrm{As}_{8} \mathrm{~S}_{8}\right)-\left(\mathrm{As}_{8} \mathrm{~S}_{9}\right)$ was shown to be conclusive evidence for an artificial origin for orpiment [14].

In this work we investigated green and yellow pigments in Japanese woodblock prints dating to the late Edo (1615-1868) and early Meiji period (1868-1912). A collection of 30 dated prints ranging from 1864 to 1887 (Table 1) was assembled by one of the authors with the purpose of examining the chronology of the introduction of synthetic organic dyes in Japan (a paper on this topic is forthcoming). In the course of this study we initially surveyed the prints in all colored areas with X-ray Fluorescence Spectroscopy. The discovery of arsenic in the yellow and green areas, usually interpreted as a sign of the use of the pigment orpiment $\left(\mathrm{As}_{2} \mathrm{~S}_{3}\right)$ was rather interesting. Yellow pigments traditionally used in Japan for painting include orpiment, yellow earth, gamboge, and berberin $[19,20]$. A recent study by Yamato [21] on Japanese prints dating to 1811-29 and 1836-91 similarly noted a widespread use of arsenic containing pigments for yellow and green areas, with turmeric often present in the yellow area.

For woodblock prints, a commercial form of art, the use of cheaper pigments is generally expected, making the use of natural orpiment, usually an expensive pigment, quite unlikely. In her study, Yamato used the appearance of the pigment under optical microscopy observation to distinguish between synthetic and natural arsenic sulfides. In this study, we offer a fully multianalytical classification based on optical microscopy, Raman microscopy, and Scanning Electron microscopy with Energy Dispersive Spectrometry.

\section{Methods}

\section{Samples}

30 Japanese prints dated from 1864 to 1887 were selected for the analyses. A complete list of the prints alongside with their titles and authors is reported in Table 1.

A multi-technique approach, which includes micro$\mathrm{X}$-ray fluorescence, micro-Raman spectroscopy and Scanning Electron Microscopy equipped with Energy Dispersive Spectrometry, was followed in this study. The use of X-ray Diffraction was ruled out because of the small dimensions of the pigment particles and the low pigment coverage, which would have resulted in unacceptably large samples.

\section{Micro-XRF}

Micro X-ray fluorescence (micro-XRF) measurements were acquired with a Bruker ARTAX 400 instrument using unfiltered $\mathrm{Rh}$ radiation at $50 \mathrm{kV}, 700 \mu \mathrm{A}$. Spectra were acquired with a $1 \mathrm{~mm}$ collimator for $120 \mathrm{~s}$ live-time accumulations.

\section{Micro-Raman spectroscopy}

Micro-Raman spectra were acquired with using a Bruker Senterra $^{\mathrm{TM}}$ dispersive Raman microscope system, operating at $785 \mathrm{~nm}$. Raman spectra were acquired directly from the prints using an Olympus LMPlanFL $50 \times$ long working distance objective, at a spectral resolution of $3-5 \mathrm{~cm}^{-1}$ and $30 \mathrm{~s}$ integration time. To avoid degradation or heat induced physical changes, the power at the laser injection port was limited to $1 \mathrm{~mW}$. Integration times of $30 \mathrm{~s}$ were employed and three accumulations were averaged for each spectrum to obtain an adequate signal-tonoise ratio. Spectra were acquired and processed using the Opus 7.0 Raman software.

\section{SEM-EDS}

Pigment coated paper fiber samples for SEM-EDS analysis were mounted on aluminum stubs using a carbon adhesive tab and coated with a $10 \mathrm{~nm}$ carbon layer. SEM analyses (backscattered electron images and point analyses) were performed with a FE-SEM Zeiss Eigma HD, equipped with an Oxford Instrument X-MaxN 80 SDD detector. EDS microanalyses were run at $20 \mathrm{kV}$ acceleration voltage and a working distance of $8.5 \mathrm{~mm}$. Data were acquired and processed using the AZtec software system, v. 2.2 SP2 (Oxford Instruments).

\section{Results and discussion}

The majority of data was initially acquired by using nondestructive techniques, and for all the prints the same analytical approach was followed: XRF was systematically run on all the colored portions of each print, then, according to the elemental composition Raman measurements were acquired on selected areas. Finally, selective sampling was carried out to proceed with SEM-EDS analyses.

\section{$\mathrm{XRF}$}

XRF data for green and yellow areas show the presence of arsenic and sulfur with other minor elements, notably iron, due to the paper matrix. The iron concentration seems higher in the green areas, possibly reflecting the use of Prussian blue mixed with the yellow to obtain the green shade.

\section{Micro-Raman spectroscopy}

Raman measurements were collected on both green (Fig. 1) and yellow (Fig. 2) areas from all the prints. Spectra resulting from the arsenic containing green- and yellow-colored areas display the same characteristic features 
Table 1 List of the prints analyzed in this research, complete of dates, authors, and titles

\begin{tabular}{|c|c|c|c|}
\hline No. & Date & Artist & Title \\
\hline 1 & 1864 & Yoshitsuya & $\begin{array}{l}\text { No. 35, Nakanuma Chûbei attacks Michihide in the Dark of Night (Nakanuma Chûbei an'ya ni Michihide o tsuku), } \\
\text { from the series "Fifty-four Scenes from the Story of Hideyoshi" (Hisago gundan gojûyojô) }\end{array}$ \\
\hline 2 & $1865 / 10$ & Kunichika & The actor Kawarazaki Gonjûrô, from the series "Shindô Suikoden \\
\hline 3 & $1867 / 04$ & Kunichika & Death memorial portrait (shini-e) of the actor Kawarazaki Kunitarô, d. 1867-04-21, age 19 \\
\hline 4 & $1868 / 11$ & Hiroshige III & Daimon Gate at Shiba Zôjôji Temple, from the series Famous Views of Tokyo (Tôkyô meishô zue) \\
\hline 5 & $1869 / 01$ & Kunichika & The Cleaning-up Job (Ato kara gakari), from the series, Thirty-two Fashionable Physiognomies (Tôsei sanjûnisô) \\
\hline 6 & $1870 / 05$ & Kunichika & $\begin{array}{l}\text { Nakamura Chûzô as Konkara-bô and Sawamura Tosshô as Seikô-bô in the kabuki play "Oni mo jûshichi." Possibly one } \\
\text { panel of triptych }\end{array}$ \\
\hline 7 & $1870 / 11$ & Kunichika & $\begin{array}{l}\text { Kuruma-ôgi restaurant, Shinmei-mae, with geisha Matsutoku of Shinmei, from the series "Tôkyô sanjûroku kaiseki" } \\
\text { (Thirty-six famous restaurants in Tokyo) }\end{array}$ \\
\hline 8 & ca. 1872 & Yoshitaki & $\begin{array}{l}\text { The three brothers in the kabuki play Sugawara denju tenarai kagami" (Sugawara and the Secrets of Calligraphy): } \\
\text { Arashi Rikan as Sakura-maru, Nakamura Fukusuke as Umeo-maru, and Ōtani Tomoemon as Matsu-o-maru. } \\
\text { Chûban triptych, Osaka }\end{array}$ \\
\hline 9 & 1872 & Shôsai Ikkei & Ikenohata Shinobazu Benten, from the series "Tôkyô meisho sanjûroku gesen" (Thirty-six Comic Views of Tokyo) \\
\hline 10 & $1872 / 10$ & Yoshitora & Hamamatsu, from the series "Shoga gojûsan eki" (Calligraphy and Pictures for the Fifty-three Stations of the Tôkaidô) \\
\hline 11 & 1873/09 & Kunichika & $\begin{array}{l}\text { Kawarazaki Gonnosuke as Nanbei (actually Abe no Munetô) in Adachigahara in Ōshû (Ōshû Adachigahara). Center } \\
\text { panel of triptych }\end{array}$ \\
\hline 12 & $1874 / 10$ & Adachi Ginkô & Bandô Hikosaburô as Yakko in the kabuki play Kotobuki Utsubozaru. Right sheet of triptych \\
\hline 13 & $1875 / 04$ & Yoshitoshi & Police raid on unlicensed prostitutes, illustration of news story from No. 425 of Yûbin Hôchi Shinbun \\
\hline 14 & $1877 / 04$ & Chikanobu & Nos 5-8, in series Lineage of the emperors of Japan (Honchô Kôtôki) \\
\hline 15 & $1877 / 02$ & Shôzan & News from Kagoshima (Kagoshima Nippô) \\
\hline 16 & $1877 / 05$ & Yoshitora & The Two Generals Face off at the Battle of Kawanakajima in Shinshû (Shinshû Kawanakajima ryôshô jikisen no zu) \\
\hline 17 & $1878 / 01$ & Kunichika & $\begin{array}{l}\text { Shinagawa-machi Manrin Restaurant from the series Thirty-six Restaurants of Enlightenment (Kaika sanjûroku } \\
\text { kaiseki) }\end{array}$ \\
\hline 18 & $1878 / 10$ & Hôsai Baidô & Nakamura Sôjûrô as Chichibu Shigetô in kabuki play “Nichô no yumichigusa no Shigetô." Center panel of a triptych \\
\hline 19 & ca 1878 & Chikashige & $\begin{array}{l}\text { Kyôbashi Brick Buildings (Kyôbashi rengaishi), from the series Beauties in the Famous Places of Tokyo (Tôkyô meisho } \\
\text { bijin awase) }\end{array}$ \\
\hline 20 & $1879 / 03$ & Kunitoshi & $\begin{array}{l}\text { The courtesan Ô-Yodo of Kinkanrô, from the series A Ranking of the Pleasure Quarters (Hana no kuruwa zensei } \\
\text { kurabe) }\end{array}$ \\
\hline 21 & 1879/07 & Chikanobu & Lively Poetry Gathering (Uta-awase no nigiwai), with Meiji empress in the center \\
\hline 22 & 1881 & Kunitoshi & $\begin{array}{l}\text { Panorama of the Precincts of Sensôji Temple in Asakusa (Asakusa-ku Kinryûzan Sensôji keidai ichiran), from the } \\
\text { series Famous Places of Tokyo (Tôkyô meisho no uchi) }\end{array}$ \\
\hline 23 & $1881 / 01$ & Kunichika & Enjoying a comparison of the flowers of the four seasons \\
\hline 24 & $1881 / 03$ & Kunichika & Shin-Yoshiwara Hachimanrô, from the series Embellishments for Thirty-Six Flowers (Junshoku sanjûroku kasen) \\
\hline 25 & 1882/08 & Hôsai Baidô & Onoe Taganojô as Takao, from the kabuki play Mukashi hinagata date no utsushi-e. Right sheet of a triptych \\
\hline 26 & $1884 / 02$ & Chikanobu & Counting Song for Enlightened Education (Kaika kyôiku kazoeuta) \\
\hline 27 & 1885/04 & Kunichika & $\begin{array}{l}\text { Ichikawa Danjûrô as Katô Toranosuke }(\mathrm{L}) \text { and Hashiba Hisayoshi }(\mathrm{C}) \text {, and Ichikawa Sadanji as Hihôden (R), in the } \\
\text { kabuki play Hanamidoki Hisago Taikôki }\end{array}$ \\
\hline 28 & 1887 & Ikuhide & Cherry Blossoms at Asakusa Kannon Temple (Asakusa Kanzeon no sakura) \\
\hline 29 & 1893/04 & Hôsai Baidô & $\begin{array}{l}\text { From the Eighteen Great Kabuki Plays: Kanjinchô (Kabuki jûhachiban no uchi: Kanjincho). Nakamura Fukusuke as } \\
\text { Minamoto Yoshitsune, Ichikawa Danjûrô as Musashibô Benkei, and Ichikawa Sadanji as Togashi Saemon }\end{array}$ \\
\hline 30 & 1894 & Kawanabe Gyôsui & Women's Ceremonies: Poem Contests (Onna reishiki uta-awase) \\
\hline 31 & 1895 & Chikanobu & Index sheets for the series The Inner Palace of Chiyoda (Chiyoda no Ôoku) \\
\hline
\end{tabular}

across the range of prints examined: a broad band at $329-340 \mathrm{~cm}^{-1}$, with a shoulder at $365 \mathrm{~cm}^{-1}$ (Figs. 1, 2) as well as small bands at 230 and $471 \mathrm{~cm}^{-1}$. Only spectra collected from green areas exhibit an additional band at $2154 \mathrm{~cm}^{-1}$ (Fig. 1), which is the diagnostic band of Prussian blue. The band at $471 \mathrm{~cm}^{-1}$ was detected in all the prints, with variable intensity: this band and the associated bands at 150 and $217 \mathrm{~cm}^{-1}$ are characteristic of sulfur. The broad peak at $329-340 \mathrm{~cm}^{-1}$ and that at $230 \mathrm{~cm}^{-1}$ find a good match with alacranite [22]. No matches with natural orpiment were found $[23,24]$.

The strong characteristic peaks at 329 and $340 \mathrm{~cm}^{-1}$ may be attributed to the monomer units in the alacranite structure, forming the shoulder at $360 \mathrm{~cm}^{-1}$. The insert 


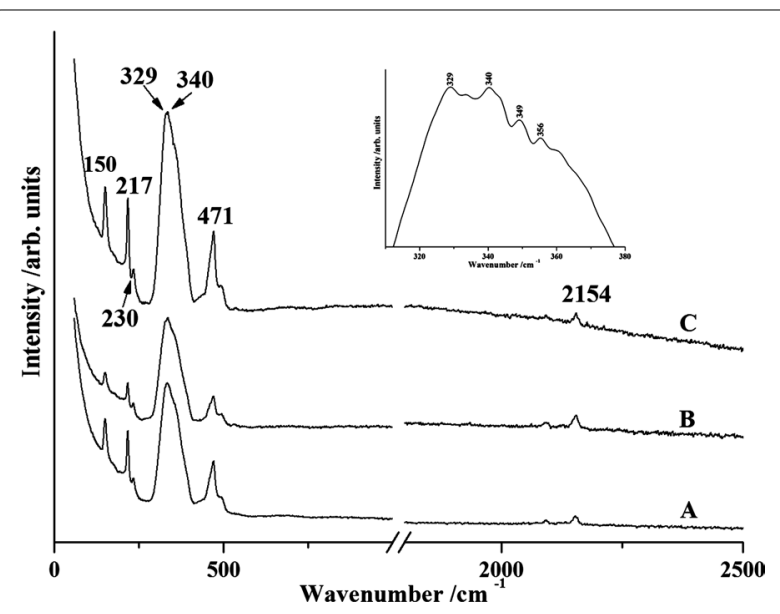

Fig. 1 Raman Spectra of selected green colored areas. A Print 5, B Print 11, C Print 27

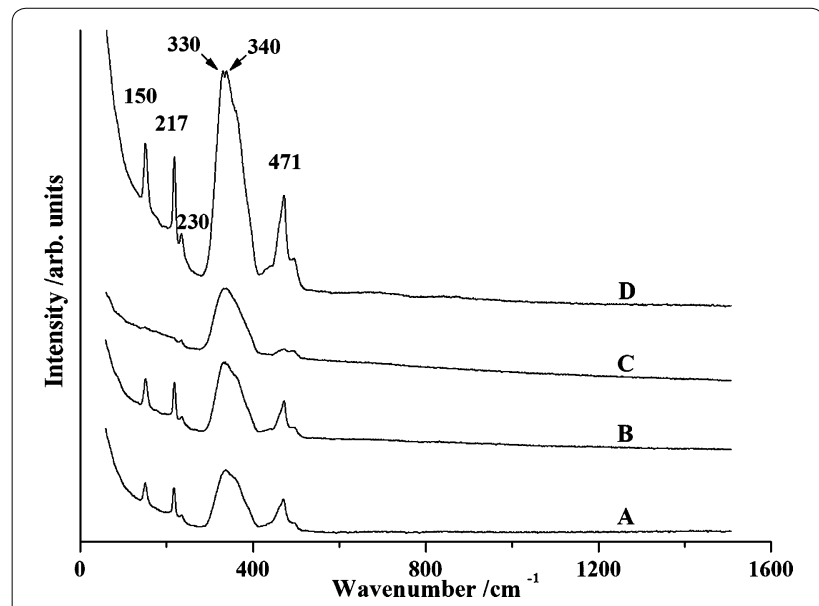

Fig. 2 Raman Spectra obtained from selected yellow colored areas. A Print 3, B Print 4, C Print 19, D Print 7

in Fig. 1 shows also the characteristic peaks at about 349 and $355 \mathrm{~cm}^{-1}$, which may be assigned to the deformation and cage breath of the monomer $\mathrm{As}_{4} \mathrm{~S}_{4}[22]$.

\section{SEM-EDS}

Backscattered electron images of some fibers taken from the yellow colored areas, display variously shaped and sized particles, scattered on single fibers (Fig. 3). Some particles show an irregular, elongated shape with sharp edges and sizes up to $13 \mu \mathrm{m}$ (Fig. 3a). Rare particles are very small spheres (Fig. 3b), up to $8 \mu \mathrm{m}$ in size, perfectly round and smooth. Semi-quantitative EDS microanalyses have been performed on both these particle typologies, and all showed similar compositions, with an average sulfur content of $53.8 \pm 3.9$ wt $\%$ and arsenic of $45.2 \pm 3.8 \mathrm{wt} \%$. This composition is consistent with that of arsenic sulfide pigments, with sulfur unusually exceeding the arsenic concentration. Similar compositions have been detected also in the arsenic sulfide pigments used to decorate the Japanese tower in Laeken, Belgium [13]. These results are not consistent with the use of a natural arsenic sulfide (e.g., orpiment), as none of the observed particles did exhibit the foliated structure of natural orpiment and the chemical compositions are non-stoichiometric. It is worth to note that every arsenic sulfide particle is characterized by the presence of copper as minor component. No $\mathrm{As}_{2} \mathrm{O}_{3}$ particles have been observed on the selected fibers.

\section{Discussion}

In all the prints from late Edo to Meiji period analyzed in this study, the systematic presence of arsenic and sulfur for the yellow and green colors indicates the use of arsenic sulfide-based pigments. This is consistent with results obtained by Yamato [21].

Micro-Raman spectroscopy showed the presence of alacranite and sulfur in the yellows, with additional Prussian blue added to obtain the green shades. The mixture of arsenic sulfide and Prussian blue explain the higher iron concentration detected by XRF in the green pigments. The broadening of the alacranite bands in the range between 329 and $340 \mathrm{~cm}^{-1}$, indicative of the presence of amorphous arsenic sulfide glass is consistent with the use of synthetic arsenic sulfides as shown by Vermeulen et al. [13]. Likewise, the presence of free sulfur has been interpreted by Vermeulen et al. [13] as due to the dry-process method used to synthesize the pigment. SEM-EDS analyses further strengthen this hypothesis, since the presence of alacranite spherules (Fig. 3b), with non-stoichiometric ratio between arsenic and sulfur, is indicated in literature as the evidence for synthetic arsenic sulfides produced by dry-process rather than a wetprocess method $[2,14,15]$. Interestingly, the analyses of the Aizu synthetic arsenic sulfide pigment carried out by Takamatsu in 1878 also show excess free sulfur [25].

The production of arsenic sulfides by sublimation from burning arsenolite and sulfur, dates back to the fourteenth century in Western Europe, but no sources have been found about their production in East Asia. The only reference known, that of Takamatsu in 1878 [25], refers to a possible production of artificial orpiment in Japan in about 1846, by burning arsenical stones with sulfur, in Aizu (in the present Fukushima prefecture). The very low concentration of copper may be explained by the exploitation of arsenic ores related to copper mining, largely attested in Japan [26-28]. 


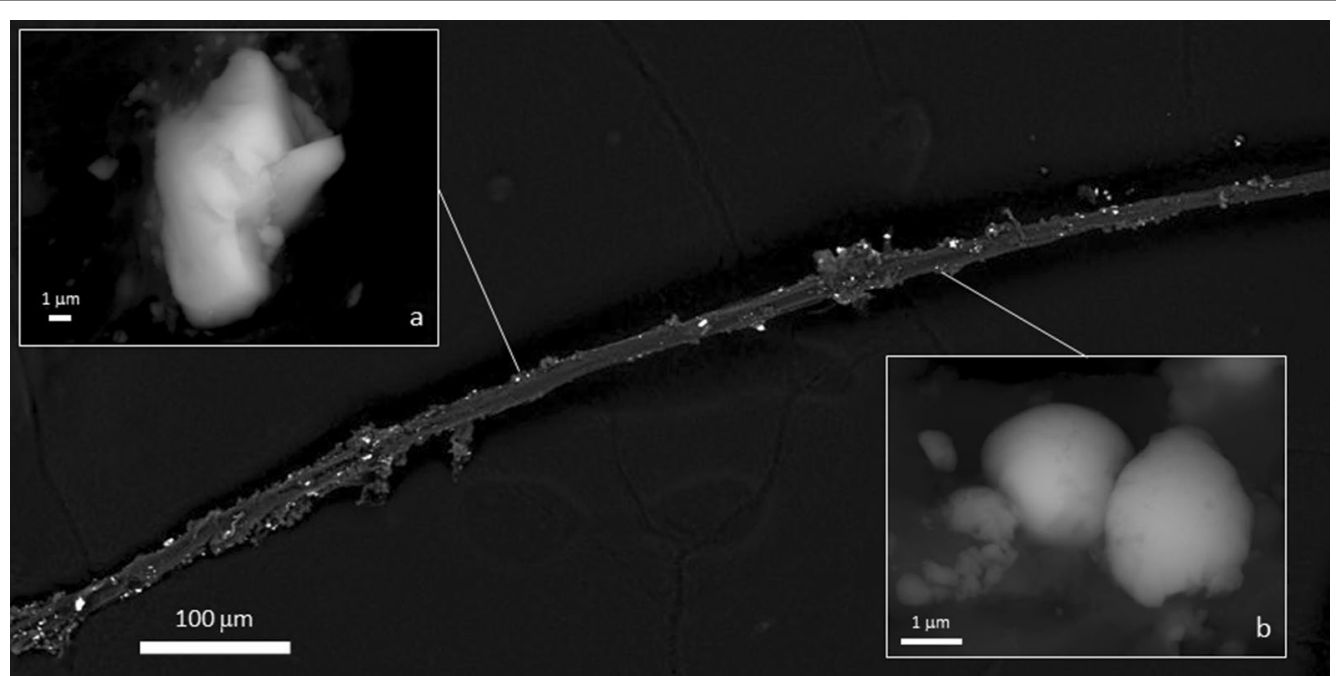

Fig. 3 Back-scattered Electron image of a yellow colored fiber from Print 2, Kunichika, The actor Kawarazaki Gonjûrô, from the series Shindô Suikoden. a prismatic particle of arsenic sulfide; $\boldsymbol{b}$ spherical arsenic sulfides

\section{Conclusions}

The evidence presented in this study demonstrates that synthetic arsenic sulfide pigments were most likely manufactured in Japan in the late Edo period and in the early Meiji period. We show conclusively that this pigment was commonly used in woodblock printing, probably due to its low cost and easy availability. Takamatsu [25] reports "large scale" manufacture of orpiment in the Aizu region in northern Japan, and mentions the use of the pigment for tinting varnishes and painting book covers. No mention is made however of its use for woodblock prints. Takamatsu reports also that manufacture of synthetic orpiment would have started after 1846: while it is tempting to correlate this report with the finding of realgar (likely available and mined in the prefecture of Gunma) in several Edo period prints in the collection of the Metropolitan Museum of Art (results unpublished), a full study of arsenic pigments in Edo period woodblock prints will need to be carried before giving excessive weight to this date.

Finally, Takamatsu's article also allows us to compare the price of artificial orpiment with that of gamboge, an imported and expensive yellow pigment also traditionally used on woodblock prints. The price of synthetic orpiment is quoted as $42 \mathrm{sen}$ per $1 \mathrm{kin}$, while that of gamboge is 1.35 yen per 1 kin. At 100 sen to the yen, synthetic orpiment is less than one third the price of gamboge, making it a very attractive pigment for the woodblock printing trade.

\section{Authors' contributions}

The prints selected for analyses were assembled and dated by HDS, II. XRF and Raman data was collected by YL. SEM-EDS analyses were carried out by EB. The manuscript was prepared by $Y L, E B$, and ML. All authors read and approved the final manuscript.

\section{Author details}

1 School of History and Culture, Center for Archaeological Science, Sichuan University, 29 Wangjiang Road, Chengdu 610064, China. ${ }^{2}$ Department of Scientific Research, The Metropolitan Museum of Art, 1000 Fifth Avenue, New York, NY 10028, USA. ${ }^{3}$ Department of East Asian Languages and Cultures, Columbia University, 420 West 118th Street, New York, NY 10027, USA.

\section{Acknowledgements}

YL gratefully acknowledges the support of the Advanced Interdisciplinary Innovation Research Project of Sichuan University (skqy201216).

\section{Competing interests}

The authors declare that they have no competing interests.

Received: 10 February 2016 Accepted: 10 May 2016

Published online: 05 July 2016

\section{References}

1. FitzHugh EW. Orpiment and realgar. In: FitzHugh EW, editor. Artists' pigments: a handbook of their history and characteristics, vol. 3. Washington D.C: National Gallery of Art; 1997. p. 47-79.

2. Grundmann G, Rötter C. Artificial orpiment: microscopic, diffractometric and chemical characteristics of synthesis products. In: Schuller M, Emmerling E, Nerdinger W, editors. Auripigment-Studien zu dem Mineral und den künstlichen produkten/Orpiment-Studies on the mineral and the artificial products. Materialen aus dem Institut für Baugeschichte, Kunstgeschichte und Restaurierung mit Architekturmuseum der technischen Universität München, Anton Siegl, Fachbuchhandlung GmbH. Munich; 2007. p. 103-66.

3. Bonazzi P, Bindi L, Olmi F, Menchetti S. How many alacranites do exist? A structural study of non-stoichiometric $\mathrm{As}_{8} \mathrm{~S}_{9}-x$ crystals. Eur J Miner. 2003;15(2):283-8.

4. Bryndzya LT, Kleppa OJ. Standard molar enthalpies of formation of realgar $\left(\mathrm{As}_{4} \mathrm{~S}_{4}\right)$ and orpiment $\left(\mathrm{As}_{2} \mathrm{~S}_{3}\right)$ by high-temperature direct-synthesis calorimetry. J Chem Thermodyn. 1988;20:755-64.

5. Roberts AC, Ansell HG, Bonardi M. Pararealgar, a new polymorph of AsS, from British Columbia. Can Miner. 1980;18:525-7.

6. Trentelman K, Stodulski L, Pavlosky M. Characterization of pararealgar and other light-induced transformation products from realgar by Raman microspectroscopy. Anal Chem. 1996;68(10):1755-61.

7. Bonazzi P, Menchetti S, Pratesi G. The crystal structure of pararealgar, $\mathrm{As}_{4} \mathrm{~S}_{4}$. Am Miner. 1995;80:400-3. 
8. Rosalie DA, Edwards HGM, Farwell DW, De Faria DLA. Raman spectroscopic analysis of ancient Egyptian pigments. Archaeometry. 2001:43(4):461-73.

9. El Bakkali A, Lamhasni T, Haddad M, Ait Lyazidi S, Sanchez-Cortes S, Puerto Nevado ED. Non-invasive micro Raman, SERS and visible reflectance analyses of coloring materials in ancient Moroccan Islamic manuscripts. J Raman Spectrosc. 2013:44(1):114-20.

10. Burgio L, Clark RJ, Muralha VS, Stanley T. Pigment analysis by Raman microscopy of the non-figurative illumination in 16th-18th century Islamic manuscripts. J Raman Spectrosc. 2008;39(10):1482-93.

11. Emelina AL, Alikhanian AS, Steblevskii AV, Kolosov EN. Phase diagram of the As-S system. Inorg Mater. 2007:43(2):95-104.

12. Popova VI, Popov VA, Clark A, Polyakov VO, Borisovski SE. Alacranite $\mathrm{As}_{8} \mathrm{~S}_{9}$ : a new mineral. In: Proceedings of the Russian mineralogical society (ZVMO); 1986. p. 360-68.

13. Vermeulen M, Sanyova J, Janssens K. Identification of artificial orpiment in the interior decorations of the Japanese tower in Laeken, Brussels, Belgium. Herit Sci. 2015:15:3-9.

14. Grundmann G, Richter M. Current research on artificial arsenic sulphide pigments in artworks: a short review. CHIMIA Int J Chem. 2008;62(11):903-7.

15. Grundmann G, Ivleva N, Richter M, Stege H, Haisch C. The rediscovery of sublimed arsenic sulphide pigments in painting and polychromy: applications of Raman microspectroscopy. In: Studying old master paintings: technology and practice. The National Gallery Technical Bulletin 30th Anniversary Conference Postprints; 2011. p. 269-76.

16. Merrifield MP. In: Original treatises dating from the XIIth to XVIIIth centuries on the arts of paintings, in oil, miniature, mosaic and on glass. Originally published John Murray, London, 1849. New York: Dover Publications; 1999. p. 78-9.
17. Cennino C. II libro dell'arte della pittura: il manoscritto della Bibliotheca Nazionale Centrale di Firenze, con integrazioni dal codice riccardiano. Torresi AP, Liberty House, Ferrara; 2004

18. Wallert A. Orpiment and realgar. Maltechnik-Restauro. 1984;90(4):45-57.

19. FitzHugh EW. Pigments in later Japanese paintings. In: Freer Gallery of Art Occasional papers, new Series, Vol 1. Washington DC: Smithsonian Institution; 2003. p. 1-56.

20. Winter J. East Asian Paintings Materials. London: Archetype Press; 2008. p. 13-44

21. Yamato A. Kôki ukiyo-e hanga ni shiyô sareta shikizai no hensen ni kansuru kenkyû (Studies on changes in the colorants used in later ukiyo-e prints). Japan: MA thesis, Tohoku University of Art and Design; 2013.

22. Pagliai M, Bonazzi P, Bindi L, Muniz-Miranda M, Cardini G. Structural and vibrational properties of arsenic sulfides: Alacranite $\left(\mathrm{As}_{8} \mathrm{~S}_{9}\right)$. J Phys Chem A. 2011;115(17):4558-62.

23. Bell IM, Clark RJ, Gibbs PJ. Raman spectroscopic library of natural and synthetic pigments (pre- $\approx 1850$ AD). Spectrochim Acta Part A Mol Biomol Spectrosc. 1997;53(12):2159-79.

24. Burgio L, Clark RJ. Library of FT-Raman spectra of pigments, minerals, pigment media and varnishes, and supplement to existing library of Raman spectra of pigments with visible excitation. Spectrochim Acta Part A Mol Biomol Spectrosc. 2001:57(7):1491-521.

25. Takamatsu T. On Japanese pigments. Tokyo: Department of Science; 1878

26. Geerts AJC. Useful minerals and metallurgy of the Japanese. Trans Asiat Soc Jpn. 1883;3:1-16.

27. Plunkett FR. Report on the mines of Japan. Jpn Mail. 1876;7(1):74-81.

28. Matsubara S, Miyawaki R. Pararealgar and alacranite from the Nishinomaki Mine, Gunma Prefecture, Japan. Bull Natn Sci Mus Tokyo. 2005;31:1-6.

\section{Submit your manuscript to a SpringerOpen ${ }^{\circ}$ journal and benefit from:}

- Convenient online submission

- Rigorous peer review

- Immediate publication on acceptance

- Open access: articles freely available online

- High visibility within the field

- Retaining the copyright to your article

Submit your next manuscript at $\boldsymbol{\nabla}$ springeropen.com 